\title{
THE AVAILABILITY OF RAW MATERIALS AND MANPOWER AND ITS INFLUENCE ON INCREASED INCOME OF RATTAN INDUSTRY CRAFTSMEN IN BIYODO HAMLET, GRESIK
}

\author{
Pudjowati Juliani ${ }^{\star}$, Wahyuni Susi Tri, Astuti Puji \\ Department of Economics, University of Bhayangkara, Surabaya, Indonesia \\ Putra Widiawan Ardiamsyah \\ Department of Accounting, University of Bhayangkara, Surabaya, Indonesia \\ *E-mail: juliani@ubhara.ac.id
}

\begin{abstract}
This research aimed at testing and discovering the availability of raw materials and manpower in rattan industry craftsmen in Biyodo Hamlet, Gresik Regency. The difficulty in obtaining high-quality raw materials was due to the fact that these craftsmen used fitrit rattan waste as their raw material and lacked productive and expert manpower in their field. It was a descriptive quantitative study. The questionnaire was distributed to 30 workers. The data were analyzed using multiple linear regression analysis. The analysis result indicated that raw materials and manpower had a simultaneous and significant influence on income, raw materials and manpower also had a partial and significant influence on income, raw materials had a dominant influence on income.
\end{abstract}

\section{KEY WORDS}

Raw materials, Manpower, Income, Crafts Industry, Rattan Biyodo Gresik.

Industry sector has been a driving force for the growth and development of an economy for it can give more productive benefits than other sectors such as agriculture and others. This is because industrial products always have higher more profitable term of trade and greater value added than other sectors' products. Additionally, the industry sector also diverse product variations which can give their users marginal benefits (Machmud, 2016). According to Maryunani (2018) and Arsyad (2016), in this context the role that industries play will be able to trigger and drive the development of other sectors which lead to expansion of job opportunities and, in turn, will increase the people's income and demand (purchasing power). These increased income and purchasing power show that the economy grows and is healthy.

Considering the importance of industry sector, the government through the Law (UU) Number 3 Year 2014 concering Industry has established industry as one of its economy's pillar. This Law has proven a relatively significant support given by the government to drive the industry forward in a well-planned manner. The industry sector in Gresik Regency can serve as one of the economic trestles and Gresik has been one of industry areas with at least 1,423 minor and major industries, making it famous as an industrial area. Three main sectors support the Gresik's economy wheels. One of them is the processing industry which gave the highest contribution to its PDRB value and grew significantly from Rp 39,960,124.3 in 2013 to Rp 56,877,420.8 in 2017. Meanwhile, the mining and excavation business fields became the second highest contributor yet they were then outmatched in the last 3 years by

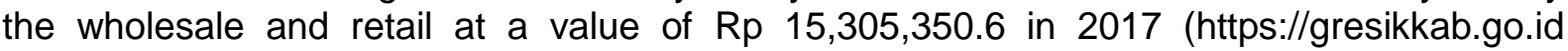
accessed 16-04-2019).

The rattan crafts industry in Biyodo Hamlet, Gresik Regency is one of the processing industries in Gresik. The existence of this rattan crafts industry in Gresik has been an alternative to earn income to meet daily needs. The more income people earn, the more fulfilled their needs. The amount of income earned will affect the business scale and people's welfare rate. The income in industry sector and household crafts can be seen from the total 
income or the amount of production or sales results minus the costs spent during the production process. The higher the production made, the more likely the income to increase. As found by Mahayasa and Yuliarmi's (2017) research, capital and manpower have a positive and significant influence on income of wood carving crafts in Tembuku District. Likewise, Suartawan and Purbadharmaja (2017) also find that capital, raw materials and production have a direct and significant influence on income of wood statue crafts industry at Sukawati District, Gianyar Regency. Meanwhile, Laksana and Jember's (2018) research finds that manpower and raw materials have an indirect influence on income through production, or in other words, production is the variable which mediates the influence of manpower and raw materials variables on income of wood craftsmen in Gianyar Regency.

The researcher was interested to conduct a study on rattan crafts industry in Biyodo Hamlet, Gresik Regency. A pre-survey was carried out to figure out the obstacles they encountered, including their difficulty in finding high-quality raw materials. So far, the owners of rattan handcrafts industry only relied on the rattan wastes delivered by major rattan factories. This rattan waste was known as ftrit. Other than raw materials, they also encountered a problem in terms of manpower, i.e. they lack productive-age and skillful manpower. This was because some of the craftsmen who were residents of Biyodo Hamlet at productive age and having minimum level of education preferred leaving the town or working in other towns.

Based on the explanation, in order to increase the income of a business, attempts needed to be made which influenced the income of rattan craftsmen in Biyodo Hamlet such as raw material and manpower. The research questions were as follows: a) Do raw materials have a significant influence on income of rattan crafts industry in Biyodo Hamlet, Gresik? b) Does manpower have a significant influence on income of rattan crafts industry in Biyodo Hamlet, Gresik?

\section{LITERATURE REVIEW}

The industrialization process and development are actually a way of increasing people's welfare in two senses at once, i.e. more advanced life level and higher quality of standard of living. This industrialization process is an attempt to improve manpower productivity which is equipped with an effort to expand the scope of human activity (Arsyad, 2016:442). According to the Indonesian Statistics (BPS, 2017), classifications of industries based on these criteria can be divided into four, namely:

- Major industry, if it employs 100 workers or more;

- Medium industry, if it employs 20-99 workers;

- Minor industry, if it employs 5 to 19 workers;

- Micro industry, if it employs less than 5 workers, including the unpaid ones.

The term income (Amir, 2014) means the profit obtained from a company's main product sales, be it in the form of goods or services as the core business. However, income can also be defined as a sum of money usable to a family within a certain period to be spent without neither reducing nor increasing their Nett assets. Sources of economic income include wage, salary, interest from deposit, rental income, transfer from the government and so forth (Rahardja and Manurung, 2014:295).

Raw materials are defined by Maskan, et al. (2018:87) as every material which belongs to the production process directly. Materials are objects or goods which can be or are used to make something, be it finished or semi-finished products. Therefore, a balance is needed in raw material supply to save the investmet and capital. Meanwhile, the factors which can affect raw material supplies are: tangible goods stocks, raw material quality, and raw material price. The existence of materials in both large and small number creates its own risk. When it is available in large number, it has the risk of loss, damage and great costs for purchase and maintenance and when it is available in small number, it has the loss of deficiency.

According to the Law No.13 Year 2003 Chapter I article I paragraph 2, it is stated that worker is everyone able to do a job in order to produce goods and/or services both for fulfilling his/her own or people's needs. The definition of manpower according to Machmud 
(2016) is any member of population within working age (15-64 years old) or the number of population in a country capable of producing goods and services if there is a demand of their services, and if they are willing to participate in the activity. Sedarmayanti (2017) suggests that manpower planning includes a). manpower productivity where the government by involving the business world element in the society provides a coaching regarding all types of manpower-related activities the implementation of which is done in an integrated and coordinated manner, b). The industrial relationship applicable in Indonesia is known as Pancasila industrial relationship. This Pancasila industrial relationship is directed to build a harmonious relationship on the basis of parallel and integrated partnership between the actors in production processes, c) Wage, every worker is entitled to obtain a feasible income for humanity. To realize this feasible income, the government establishes protection of waging for workers.

\section{METHODS OF RESEARCH}

This research used census sampling where the samples were all those working for rattan crafts industry at Biyodo Hamlet, Gresik amounting to 30 workers.

The researcher collected the data by observing the respondents directly and indirectly. The questionnaire which was in the form of written questions was then completed and finally interviews were done to complement the questionnaire.

Validity test, valid data are those "which did not contain any difference" between what are reported by researchers and what are actually happening to the research objects.

Reliability test, A questionnaire is said to be reliable or dependable if one's answers to questions are consistent or stable from time to time.

The analyses used to answer the questions or hypotheses in this research were t-test and f-test. Testing it statistically and using SPSS (Statistic Produk and Service Solution) for windows version 25.0 program, it was expected the analysis result could be used as a benchmark to find out to what extent all independent variables influenced the dependent variable. To discover the effect of independent variables on the dependent variable, the statistic test of multiple linear regression was used. Meanwhile, the regression model used in this research was:

$$
Y=\beta_{0}+\beta_{1} X_{1}+\beta_{2} X_{2}+\beta_{3} X_{3}+e \text { (Sugiyono, 2017) }
$$

Where: $Y$ - Income; $\beta_{0}$ - regression equation constant; $\beta_{1}-\beta_{3}$ - independent variable coefficient; $\mathrm{X}_{1}$ - Raw materials; $\mathrm{X}_{2}$ - Manpower.

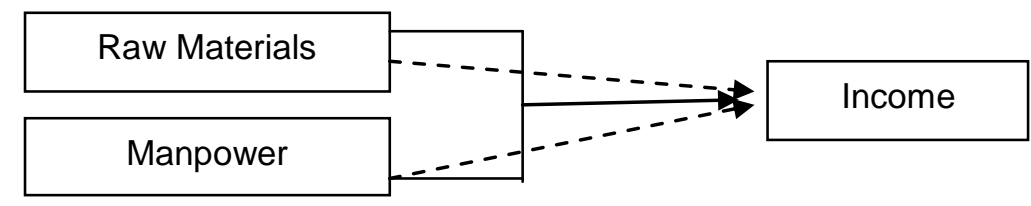

Figure 1 - Conceptual Framework

Correlation between Raw materials and Income. All raw materials directly belonging to a production process were goods or objects which could be or were used to make something, be it in the form of either goods or semi-finished goods. The existence of materials in both large and small number creates its own risk. When it is available in large number, it has the risk of loss, damage and great costs for purchase and maintenance and when it is available in small number, it has the loss of deficiency. Suartawaan and Purbadharmaja (2017) suggested that the greater the number of raw materials owned, the greater the possibility of the number of products produced, thus it was more likely that the income earned would be greater from the production sales result.

$\mathrm{H}_{1}$ : The raw material variable has a partial influence on income in rattan crafts industry in Biyodo Hamlet, Gresik. 
Correlation between Manpower and on Income. Manpower which means any member of population within working age (15-64 years old) or the number of population in a country capable of producing goods and services if there is a demand of their services, and if they are willing to participate in the activity. According to Wirawan and Indrajaya (2019) the manpower used was in the form of people who are able to work to provide services or attempt and capable of performing activities which result in goods/services to meet needs. The greater the number of manpower, the more number of goods would be produced. An increase to the number of manpower would have some effect on the level of income and output produced.

$\mathrm{H}_{2}$ : The manpower variable has a partial influence on income of rattan industry craftsmen in Biyodo Hamlet, Gresik.

Correlation of Raw Material and Manpower on income. Amir (2016) suggested that input was the resources used in income such as raw materials, manpower and technology. Mahayasa and Yuliarmi (2017) found that the technology variable failed to moderate the influence of manpower on production since it served only as an independent variable or it stood alone, directly influencing the business production. If the manpower increased, the income produced would also increase. Manpower indirectly influenced income through production. This meant that production was a variable which mediated the influence of manpower on income.

$\mathrm{H}_{3}$ : The raw material, manpower and technology variables have a simultaneous influence on the income of rattan industry craftsmen in Biyodo Hamlet, Gresik.

\section{DISCUSSION OF RESULTS}

Raw materials and manpower are two of many factors which could influence the income of an industry. Therefore, like any other industries the craftsmen of rattan industry also wanted to develop and gain greater advantage than other rattan handcrafts industry in general. Craftsmen needed to select raw materials with good quality to be used to make goods, yet at an affordable price. Not only raw materials, productive and expert workers were also needed in its production production because they would be helpful in creating ideas to make more varied handcrafts to match the customer's demands and tastes. Based on Table 1 , a regression equation model could then be made as follows.

$$
Y=10.113+0.252 X_{1}+0.220 X_{2}
$$

Table 1 showed that the value of determination coefficient $\left(R^{2}\right)$ was 0.432 . This indicated that the contribution of raw materials $\left(X_{1}\right)$ and manpower $\left(X_{3}\right)$ variables was $43,2 \%$, and the remaining $56.8 \%$ could be explained by other independent variables which were not included in the model of this research. Based on the result of regression coefficient, the following table was presented:

Table 1 - Result of Regression Coefficient

\begin{tabular}{|c|c|c|c|c|c|}
\hline \multicolumn{6}{|l|}{ Coefficients $^{\mathrm{a}}$} \\
\hline Model & $\begin{array}{l}\text { Unstanc } \\
\text { B }\end{array}$ & $\begin{array}{l}\text { Toefficients } \\
\text { Std. Error }\end{array}$ & $\begin{array}{l}\text { Standardized Coefficients } \\
\text { Beta }\end{array}$ & $\mathrm{T}$ & Sig. \\
\hline 1 (Constant) & 10.113 & 3.274 & & 3.088 & .005 \\
\hline Raw material & .252 & .095 & .413 & 2.662 & .013 \\
\hline Manpower & .220 & .100 & .334 & 2.187 & .038 \\
\hline
\end{tabular}

Source: Processed Data, 2019.

Based on Table 1, it could be stated that the raw material variable had a t statistic value of 2.662 with sig. 0.013 . Since to be significant it should be less than 0.05 , then $\mathrm{H}_{1}$ was accepted. Therefore, it could be concluded that raw materials had a significant influence on income. This research finding was consistent with I Komang Suartawan and 
I B. Purbadharmaja, (2017) who found that raw materials had a direct and significant influence on income of wood statue crafts industry in Sukawati District, Gianyar Regency. Another research by I Nyoman Darma Budhi Laksana and I Made Jember (2018) found that raw materials had a direct, positive and significant influence on the production of wood craftsmen in Gianyar Regency.

According to Solihin (2014:119), raw material of an industry is an integral part of the whole value of a production which could be offered by the company to customers. The raw material obtained by rattan craftsmen had the same quality as the one obtained by their competitors at lower price, thus they would have greater chance of obtaining competitive advantage than their competitors. For this reason, raw material became an integral part of the products produced by a business. Every business which organized production activity would require raw material stocks. The greater the number of raw materials owned by a business, the more likely for the number of products it produces. Thus, it is more likely for them to receive greater income from the sales of their products (Suartawan and Purbadharmaja, 2017).

Based on Table 1, it was found that manpower variable had a value of $t$ statistic of 2.187 with a significance rate of 0.038 . Since its significance rate was less than 0.05 , then $\mathrm{H}_{2}$ was accepted. It could therefore be concluded that manpower had a significant influence on income, meaning that rattan craftsmen needed not only to be capable of making a product, rather they also needed to have specific expertise in modifying the products they generated as manpower. Additionally, team work and mutual feedback on the shape of finished product were also extremely important. This research finding was consistent with Laksana and Jember (2018), Mahayasa and Yuliarmi (2017) and Wirawan and Indrajaya (2019) who found that manpower had a direct, positive, and significant influence on production of wood craftsmen in Gianyar Regency, UKM Pei Susu Denpasar.

Solihin (2014: 147) suggested that the important factors which influence the structure of an organization were the characteristics of personnel employed by a company. In general, the higher the expertise of manpower within an organization, the more they need to cooperate among themselves within a group or team to implement their tasks. Thus, the influence of manpower on production is the one which could never be separated since all productions needed manpower to obtain/make a goods or service. The increased number of production would lead to the increase in requirement for manpower, hence the income would also increase (Laksana and Jember, 2018). If many products were sold, entrepreneurs would also increase the number of their production.

Based on the result of F-test analysis, a value of $F$ statistic of 6.601 was obtained with a significance rate of 0.002 . Thus, $\mathrm{H}_{3}$ was accepted. It could then be concluded that raw materials and manpower had a significant influence on income. Procuring raw materials was the most important part of a production process in a business. Without raw materials, the production process could not proceed to process it into finished or semi-finished goods. This was because every rattan craftsman in their attempt to produce products would need raw materials. Craftsmen as manpower also participated in the production of finished products (Maliha, 2018). Technology was extremely important for use to increase the production. Additionally, technology was highly needed by entrepreneurs to keep their designs up to date and to obtain an optimal result (Nurjannah, 2018).

\section{CONCLUSION AND SUGGESTIONS}

Based on the result of analysis and discussion, it could then be concluded as follows:

- The raw material variable had a significant influence on income in Biyodo Hamlet, Gresik Regency, with a t-statistic value of 2.662 and sig. value of 0.013 . Therefore, the first hypothesis $(\mathrm{H} 1)$ was accepted;

- The manpower variable had a significant influence on income in Biyodo Hamlet, Gresik Regency, with a t-statistic value of 2.187 and sig. value of 0.038 . Therefore, the second hypothesis (H2) was accepted; 
- The raw materials, technology, and manpower variables had a simultaneous and significant influence on income in Biyodo Hamlet, Gresik Regency, with a F-statistic value of 6.601 and sig. value of 0.002 . Therefore, the third hypothesis $(\mathrm{H} 3)$ was accepted.

Based on the research results and conclusions presented, the research could then give the suggestions which would benefit those parties relevant to this research. And the suggestions the researcher could offer are as follows:

- Raw materials are the main factor in any industry. The quality of raw materials will affect the industry's products. The quality of a company's products will affect the customer's purchasing power and interest to buy. When the customer's demands and purchasing power increase, the income earned by craftsmen will also increase. Therefore, it is suggested for the local government to make some intervention to deal with this difficulty encountered by craftsmen in obtaining high-quality raw materials. Providing the right recommendations and solution, i.e. by assigning suppliers who can supply high-quality rattan at a more affordable price to allow them to produce better rattan products which can also increase the customer's purchasing power. When the customer's interest to buy product increases, the products sold will also increase;

- Manpower is an important factor in an industry. Employing adequate and qualified manpower, it is expected that industries will be able to improve its production and once the production improves, more products will be marketed and, in turn, the income they obtain will increase. For this reason, it will be even better if they have some experts and more productive manpower in their production which includes such expertises as mechanical engineering and product design. This will make them more agile in the production process and the products will also be more varied. It is also recommended to improve the products they produce and to maintain the quality as the customers expect them to be.

\section{REFERENCES}

1. Arsyad, Lincolin. 2016. Ekonomi Pembangunan, Edisi ke-5, UPP STIM YKPN.

2. Machmud, Amir. 2016. Perekonomian Indonesia pasca reformasi, Penerbit Erlangga, Jakarta.

3. Maryunani 2018. Pengelolaan Sumber Daya Alam and Pembangunan Ekonomi Secara Berkelanjutan, Penerbit UB press, Malang.

4. Maskan. Mohammad, Permatasari. Ita Rifiani and Utaminingsih. Alifiulahtin. 2018. Kewirausahaan, Penerbit Polinema Press, Malang. Mahayasa, I B Adi and Yuliarmi, Ni Nyoman 2017. Pengaruh Modal, Teknologi, and Tenaga Kerja Terhadap Produksi and Pendapatan Usaha Kerajinan Ukiran Kayu Di Kecamatan Tembuku, E-Jurnal Ekonomi Pembangunan, Universitas Udayana: Vol.6, No. 8.

5. Satya. Venty Eka, Suhartono, and Hermawan. Iwan. 2018. Pengembangan Industri Tektil Nasional, Penerbit Yayasan Pustaka Obor Indonesia, Jakarta

6. Suartawan, I Komang and Purbadharmaja, I B 2017. Pengaruh Modal and Bahan Baku Terhadap Pendapatan Melalui Produksi Pengrajin Patung Kayu Di Kecamatan Sukawati Kabupaten Gianyar, E-Jurnal Ekonomi Pembangunan, Universitas Udayana: Vol.6 No9, ISSN: 2303-0178, From https://webcache.googleusercontent.com.

7. Solihin, Ismail. 2015. Pengantar Bisnis, Penerbit Erlangga, Jakarta.

8. Wirawan, Ngurah Gede Dwiky and Indrajaya, I Gusti Bagus 2019. Pengaruh Modal and Tenaga Kerja Terhadap Produksi and Pendapatan Pada UKM Pie Susu Di Denpasar, EJurnal Ekonomi Pembangunan, Universitas Udayana: Vol.8 No. 2, ISSN: 2303-0178, From https://ojs.unud.ac.id.

9. Yeni, Nyoman Triani Arisana and Budhi Made Kembar Sri 2016. Analisis Faktor-Faktor Yang Mempengaruhi Penyerapan Tenaga Kerja and Produktivitas Kerja Patung. E-jurnal Ekonomi Pembangunan, Universitas Udayana: Vol.5, No.4. 